V.A. Gorobets, $\mathrm{PhD}$, Prof., O.P. Manoylenko, PhD, Assoc.Prof.

Kyiv National University of Technologies and Design, 2 Nemirovich-Danchenko Str., 01011 Kyiv, Ukraine; e-mail: VA1948@ukr.net

\title{
DESIGNING THE FLAT SEWING MACHINES' MECHANISMS THAT IMPLEMENT A NEW TYPE OF STITCH
}

\begin{abstract}
В.А. Горобець, О.П. Манойленко. Проектування механізмів плоскошовних швейних машин для реалізації нового типу стібка. Визначення параметрів деяких механізмів швейних машин для реалізації нових типів стібків $\epsilon$ невирішеним актуальним завданням. Запропоновано методику визначення оптимальних параметрів ланок механізмів швейних машин, які забезпечують можливість реалізації нового типу плоского ланцюгового стібка. Отримано значення параметрів механізмів машини для реалізації нового типу стібка, співставні з параметрами аналогічних механізмів машин, що виконують класичний тип стібка. Запропонована методика може бути застосована при проектуванні механізмів нових плоскошовних швейних машин.

Ключові слова: швейні машини, ланцюговий стібок, проектування механізмів.

V.A. Gorobets, O.P. Manoylenko. Designing the flat sewing machines' mechanisms that implement a new type of stitch. Defining parameters of sewing machines' some mechanisms for new types of stitches still remain an unresolved urgent task. This study presents a method for determining the optimum parameters of the sewing machine parts' mechanisms, providing the possibility of implementing a new type flat chain stitch. The obtained machinery mechanisms' parameters allowing the implementation of a new type stitch are comparable to the parameters of similar mechanisms that perform classic types of stitch. The proposed technique can be applied when designing new flat sewing machines' mechanisms.

Keywords: sewing machines, chain stitch, mechanisms‘ design.
\end{abstract}

Introduction. Defining parameters of sewing machines' mechanisms contributing to the new type of stitches making still remains an unresolved urgent task.

Analysis of recent research and publications. At sources [1,2] the authors propose the new techniques of implementing multithread chain stitches specific with a number of advantages over the known types of analogic stitches, as well as the revised structure and design of the sewing machine mechanisms.

However, several mechanisms' parameters definition using the known methods is impossible, because to form new type stitches, significant changes should be introduced not only into operations' list and sequence, but in some cases the technology principle. In other words, significantly changed is the operational routine of sewing machines.

The Aim of Research is to develop methods for determining these machines parameters, which provide reliable operation of a machine while forming new stitches.

Main Body. Methods for determining the parameters of the mechanisms implementing flat chain stitches (including the new type ones) elaborated by the authors are presented at [3]. These methods are based on analyzing the machines' synchrograms (combined working bodies' function graphs) vehicles, defining the minimum necessary working bodies' moves serving to define the specific mechanisms' parameters. These are minimum values of needle's and looper's travel that ensure the reliable contact of working bodies in the so-called moments of "loop-fallover" needle and looper interaction with consecutive loop fixation by the needle as well as the normal operation of feeding mechanism.

The classical synchrogram of flat chain stitches performing machine's working organs (feeding mechanism not inclusive) is shown in Fig. 1. The instances above are illustrated with points $B_{1} \ldots B_{4}$

DOI 10.15276/opu.2.46.2015.13

(C) 2015 The Authors. This is an open access article under the CC BY license (http://creativecommons.org/licenses/by/4.0/). 


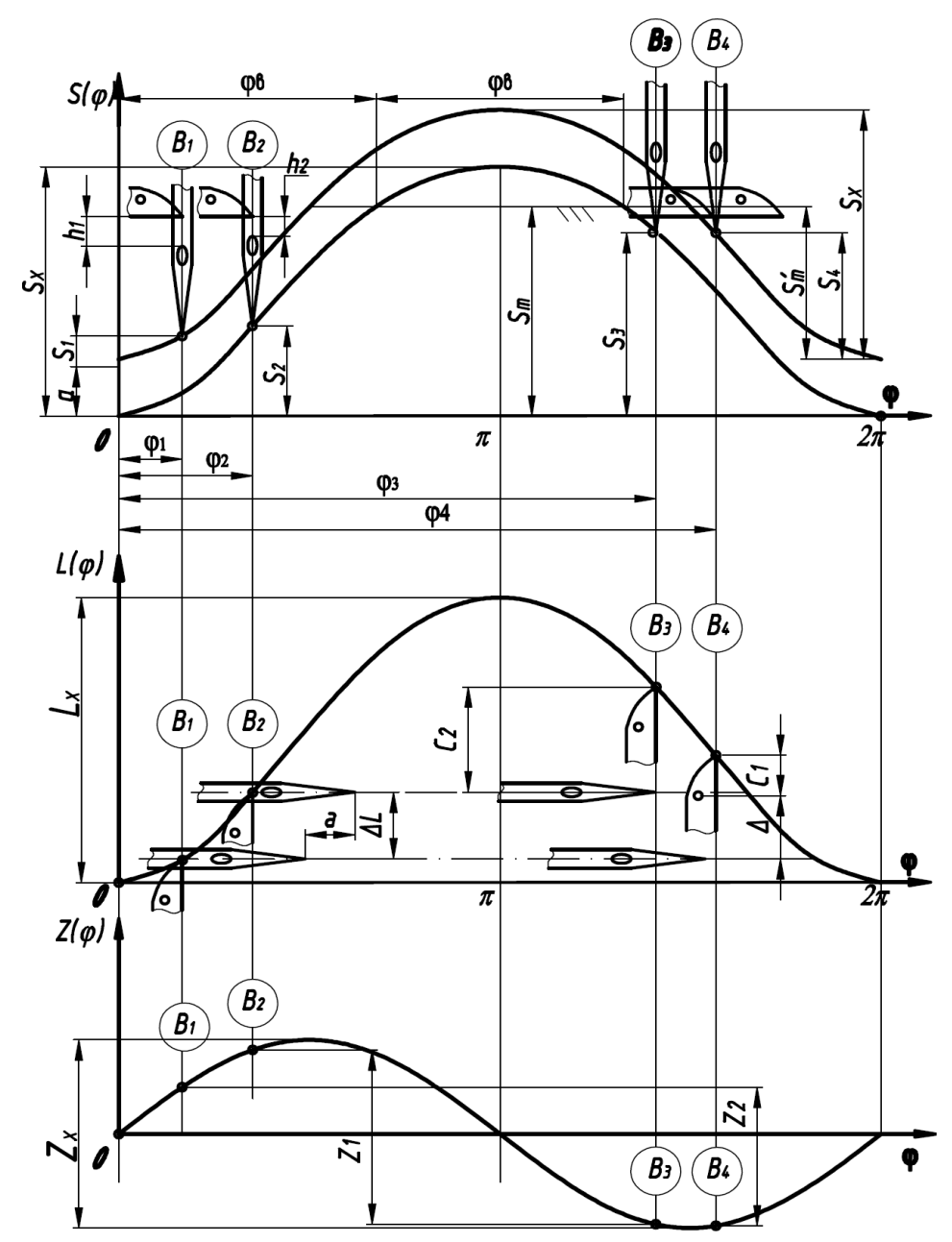

Fig 1. Working bodies' synchrogram of a sewing machine for flat chain stitches

According to [3] the minimum required needles' travel when forming a flat chain stitch is determined from the condition

$$
S_{X}=\frac{S_{M}+\Delta L / K}{f_{1}\left(\varphi_{r}\right)}
$$

where $S_{M}$ - value of the needle displacement in the material when needle's lowest position at the needle clamp. This value depends on technology (fabric thickness, type of yarn) and structure (needle type, looper design, foot and needle plate thickness) parameters and is determined by the method [4].

$\Delta L$ - distance between the extreme needles (stitch width);

$K$ - ratio of the needle carrier and the looper average velocities while the looper interacting with needles;

$\varphi_{r}$ - angle of the main shaft rotation, measured from the moment of extreme high position of the lowest needle, leaving the fabric;

$f_{1}\left(\varphi_{r}\right)$ - needle carrier position unit function,

$$
f_{1}\left(\varphi_{r}\right)=2 S(\varphi) / S_{X}
$$

$S(\varphi)$ - needle carrier position at instance $\varphi$.

In addition the needle carrier travel value should ensure the feeder's normal operation, i.e.

$$
S\left(\varphi_{r}\right)=S\left(\varphi_{r}+\varphi_{g}\right) \geq S_{m},
$$


where $\varphi_{g}$ - given angle of the main shaft rotation, which characterizes the period of lowest needle's movement over the fabric;

$S_{m}$ - lowest needle's displacement through the fabric.

The condition (2) not satisfied, the needle carrier travel value resulting from (1) should be increased accordingly.

The minimum required looper's travel across the backstitch shall ensure the four conditions of "loop-fallover" reliable capturing by each of the two needles and every loop fixation with each needle. Respectively

$$
\begin{aligned}
L_{X 1} & =\frac{C_{1}}{f_{2}\left(\varphi_{4}\right)-f_{2}\left(\varphi_{1}\right)}, \\
L_{X 2} & =\frac{C_{2}}{f_{2}\left(\varphi_{3}\right)-f_{2}\left(\varphi_{2}\right)}, \\
L_{X 3} & =\frac{\Delta L \cdot K_{0}}{f_{2}\left(\varphi_{4}\right)-f_{2}\left(\varphi_{2}\right)},
\end{aligned}
$$

where $C_{1,2}$ - looper position relative to the needle position while loop fixation instances;

$f_{2}(\varphi)$ - looper position unit function $f_{2}(\varphi)=2 L(\varphi) / L_{X}$;

$\varphi_{1 \ldots 4}$ - main shaft rotation angles that characterize the interaction points $B_{1} \ldots B_{4}$.

We have to select the greatest member of the $L_{X}$ values range obtained from the formulas (3) ... (5).

The minimum required looper travel along backstitch line is determined from dependencies

$$
\begin{aligned}
& Z_{X_{1}}=\frac{Z_{1}}{f_{3}\left(\varphi_{1}\right)-f_{3}\left(\varphi_{4}\right)}, \\
& Z_{X_{2}}=\frac{Z_{2}}{f_{3}\left(\varphi_{2}\right)-f_{3}\left(\varphi_{3}\right)},
\end{aligned}
$$

where $f_{3}(\varphi)=2 Z(\varphi) / Z_{X}$ - looper backstitch-wise position unit function;

$Z_{1,2}=d+\delta+2 f_{1,2}$ - looper backstitch-wise position at the points $B_{1} \ldots B_{4}$,

$d$ - needle diameter;

$\delta$ - looper thickness;

$f_{1,2}$ - gap between loopers and outer needles at the interaction points $B_{1}, B_{2}$ ( $\left.f_{1}=0,1 \mathrm{~mm}, f_{2}=0,2 \mathrm{~mm}\right)$.

We select the greatest value $Z_{X}$ from the range resulting from (6) and (7).

To determine the specific mechanisms' parameters we analyze the peculiarities of $B_{1} \ldots B_{4}$ points' interaction conditions when a new stitch formation. As can be seen from the dependence (5), when known types flat chain stitches formation the looper transversal travel value is directly proportional to the distance between the needles and essentially much depends on the needles' positions difference at "loop-fallover" capture moments and loops fixation, that difference value, given the working bodies' and mechanisms' design parameters is practically invariable. This leads to that the actual maximum width of the flat chain stitch at sewing machines never exceeds $5,5 \ldots 6 \mathrm{~mm}$. At the same time a new type of stitch performing the extreme needles interact each with its own looper, i.e. the points $\mathrm{B}_{1}$ and $\mathrm{B}_{2}$ are matching.

At the same time, when "fixing" moments (points $\mathrm{B}_{3}$ and $\mathrm{B}_{4}$ ) each needle interacts with a "foreign" looper. Therefore dependences (4) and (5) shall take the form 


$$
\begin{aligned}
& L_{X_{2}}=\frac{C_{1}}{f_{2}\left(\varphi_{3}\right)-f_{2}\left(\varphi_{1}\right)}, \\
& L_{X_{3}}=\frac{\Delta L \cdot K}{f_{2}\left(\varphi_{4}\right)-f_{2}\left(\varphi_{1}\right)} .
\end{aligned}
$$

By analogy the equation (7) takes the form

$$
Z_{X}=\frac{Z_{2}}{f_{3}\left(\varphi_{1}\right)-f_{3}\left(\varphi_{3}\right)}
$$

These peculiarities should be obligatorily considered when designing sewing machines for a new type of flat chain stitches.

Results. Using the above, we can define the sewing machine needles and looper mechanisms' pa-

\begin{tabular}{|c|c|c|}
\hline Parameter & symbol & value \\
\hline $\begin{array}{l}\text { Technological parameters: } \\
\text { 1. Fabric thickness } \\
\text { 2. Needle } 032 \text { GHS } \\
\text { Needle diameter } \\
\text { Needle point length } \\
\text { 3. Stitch width }\end{array}$ & $\begin{array}{c}m \\
d \\
h \\
\Delta L\end{array}$ & $\begin{array}{c}4 \mathrm{~mm} \\
0,9 \mathrm{~mm} \\
5 \mathrm{~mm} \\
6,4 \mathrm{~mm}\end{array}$ \\
\hline $\begin{array}{l}\text { Construction parameters: } \\
\text { 1. Looper width } \\
\text { 2. Looper thickness } \\
\text { 3. Needle plate thickness } \\
\text { 4. Crankshaft to crank rod dimensions ratio }\end{array}$ & $\begin{array}{l}a \\
\delta \\
b\end{array}$ & $\begin{array}{l}4 \mathrm{~mm} \\
2 \mathrm{~mm} \\
3 \mathrm{~mm}\end{array}$ \\
\hline $\begin{array}{l}\text { - needle mechanism } \\
\text { - looper mechanism }\end{array}$ & $\lambda_{1}=r_{1} / l_{1}$ & 0,3 \\
\hline lengthwise line & $\lambda_{2}=r_{2} / l_{2}$ & 0,1 \\
\hline crosswise line & $\lambda_{3}=n \cdot \sin \alpha / l_{2}$ & 0,13 \\
\hline $\begin{array}{l}\text { where } \alpha-\text { crank head inclination angle. } \\
\text { 5. Looper nose length } \\
\text { 6. Looper shaft spider length } \\
\text { 7. Needles' position height difference }\end{array}$ & $\begin{array}{c}c \\
n \\
\Delta h \\
\end{array}$ & $\begin{array}{c}5 \mathrm{~mm} \\
40 \mathrm{~mm} \\
5 \mathrm{~mm} \\
\end{array}$ \\
\hline Kinematic parameters: & & \\
\hline 1. Needle mechanism position unit function & $\frac{1}{2}\left(1-\cos \varphi+\frac{\lambda_{1}}{2} \sin ^{2} \varphi\right)$ & \\
\hline 2. Looper mechanism transversal position unit function & $\frac{1}{2}\left(1-\cos \varphi+\frac{\lambda_{2}}{2} \sin ^{2} \varphi\right)$ & \\
\hline 3. Looper mechanism longitudinal position unit function & $\frac{\lambda_{3}}{2 \lambda_{2}} \sin \varphi$ & \\
\hline 4. Needle and looper velocities ratio at the interaction instance $B_{1}-B_{2}$ & $K$ & 0,9 \\
\hline $\begin{array}{l}\text { Other parameters: } \\
\text { 1. Feeder mechanism operative run coefficient }\end{array}$ & $\frac{\varphi_{R}}{2 \pi}$ & 0,3 \\
\hline
\end{tabular}
rameters [1] to implement a new type of flat chain stitch (see Table below).

Initial data

Calculation process:

1. Defining the period of lower needle under fabric position:

$$
\varphi_{R}=0,3 \cdot 2 \pi=0,6 \pi=108^{\circ} \text {. }
$$


2. Defining the period of lower needle intra-fabric position for central-crankshaft-slider mechanism:

$$
\varphi_{m}=\pi-\frac{\varphi_{R}}{2}=180^{\circ}-\frac{108^{\circ}}{2}=126^{\circ} .
$$

3. Defining the lower needle travel distance:

$$
S_{m}=\Delta S+h+t+a+e+b+m=22 \mathrm{~mm},
$$

where $\Delta S-$ height of needle raise required for the sufficient "loop-fallover" forming. Case of chain stitch machine, $t$ - is the value characterizing the looper nose position above the needle's eye upper edge (according to [5] at these machines $\Delta S=3 \mathrm{~mm}, t=2 \mathrm{~mm}$ ), $e$ - distance from the looper upper surface to the needle plate lower surface (as designed value, $e=2 \mathrm{~mm}$ ).

4. According to (1) the needle travel will be:

$$
S_{X}=\frac{2(22+6,4 / 0,9)}{1-\cos 126^{\circ}+\frac{0,3}{2} \sin ^{2} 126^{\circ}}=34,4 \mathrm{~mm} .
$$

Respectively the needle mechanism parameters

$$
r_{1}=\frac{S_{X}}{2}=17,2 \mathrm{~mm} ; \quad 1_{1}=r_{1} / \lambda_{1}=51,6 \mathrm{~mm} .
$$

5. Then the angles values $\varphi_{1 \ldots .}$ shall be:

$$
\begin{gathered}
S\left(\varphi_{1}\right)=S_{1}=\Delta S=3 \mathrm{~mm}, \\
S\left(\varphi_{4}\right)=S_{4}=S_{m}-m-b-\Delta-e=13 \mathrm{~mm}, \\
S_{3}=S_{4}+\Delta h=18 \mathrm{~mm}
\end{gathered}
$$

where $\Delta-$ value, characterizing the needle position respectively to the looper's eye upper edge at the moment $\mathrm{B}_{3}$ (as by [4] $\Delta=1 \mathrm{~mm}$ )

For the needle's central-cranckshaft-slider mechanism according to cosinuses theorem

$$
\varphi_{1,3,4}=\arccos \frac{r_{1}^{2}-l_{1}^{2}+\left(r_{1}+l_{1}-S_{1,3,4}\right)^{2}}{2 r_{1}\left(r_{1}+l_{1}-S_{1,3,4}\right)} .
$$

thus $\varphi_{1}=30,3^{\circ}, \varphi_{3}=263^{\circ}, \varphi_{4}=302,2^{\circ}$.

6. The looper transversal is found according to (3), (8) and (9):

$$
\begin{gathered}
L_{X 1}=\frac{2 \cdot 5}{\left(\cos 30,3^{\circ}-\cos 302,2^{\circ}\right)+\frac{0,1}{2}\left(\sin ^{2} 30,3^{\circ}-\sin ^{2} 302,2^{\circ}\right)}=27,2 \mathrm{~mm}, \\
L_{X 2}=\frac{2 \cdot 5}{\left(\cos 30,3^{\circ}-\cos 263^{\circ}\right)+\frac{0,1}{2}\left(\sin ^{2} 30,3^{\circ}-\sin ^{2} 263^{\circ}\right)}=13,3 \mathrm{~mm}, \\
L_{X 3}=\frac{2 \cdot 6,4 \cdot 0,9}{\cos 302,2^{\circ}-\cos 203^{\circ}+\frac{0,1}{2}\left(\sin ^{2} 302,2^{\circ}-\sin ^{2} 263^{\circ}\right)}=17,6 \mathrm{~mm},
\end{gathered}
$$

To effect further calculation, we admit value $L_{X 1}$.

7. The looper longitudinal travel is found according to (6) and (10)

$$
Z_{X 1}=\frac{2 \cdot(0,9+2+2 \cdot 0,1) \cdot 0,1}{0,13\left(\sin 30,3^{\circ}-\sin 302,2^{\circ}\right)}=3,7 \mathrm{~mm},
$$




$$
Z_{X 2}=\frac{2 \cdot(0,9+2+2 \cdot 0,2) \cdot 0,1}{0,13\left(\sin 30,3^{\circ}-\sin 26,3^{\circ}\right)}=3,3 \mathrm{~mm}
$$

For further calculation, we admit the value $Z_{X 1}$.

Therefore the looper mechanism parameters :

— crankshaft radius $r_{2}=L_{X 1} / 2=13,6 \mathrm{~mm}$;

- rod length $l_{2}=r_{2} / \lambda_{2}=136 \mathrm{~mm}$

— crank slider (crank head) inclination angle $\alpha=\arcsin \frac{l_{2} \cdot \lambda_{3}}{n}=23,8^{\circ}$.

Conclusions. The obtained sewing machines mechanisms' parameters allowing the implementation of a new type stitch are comparable to the parameters of similar mechanisms that perform classic types of stitch. The developed calculation technique can be applied when designing new flat sewing machines' mechanisms.

\section{Література}

1. Пат. 76292 Україна, D05B 93/00. Спосіб утворення чотириниткового плоского ланцюгового стібка / Манойленко О.П., Горобець В.А.; заявник та патентовласник КНУТД. — № u201208232; заявл. 05.07.2012; надр. 25.12.2012, Бюл. № 24.

2. Пат. 78454 Україна, D05B 57/00. Сточувальна швейна машина чотириниткового ланцюгового стібка / Горобець В.А., Манойленко О.П.; заявник та патентовласник КНУТД. — № u201208227; заявл. 05.07.2012; надр. 25.03.2013, Бюл. № 6.

3. Горобець, В.А. Аналіз взаємодії робочих органів швейної машини потайного ланцюгового стібка / В.А. Горобець, О.П. Манойленко, В.М. Дворжак // Вісник КНУТД. - 2011. — № 3. - С. 9 - 15.

4. Пищиков, В.О. Проектування швейних машин / В.О. Пищиков, Б.В. Орловський. - К.: Формат, 2007. $-320 \mathrm{c}$.

\section{References}

1. Kyiv National University of Technologies and Design. (2012). Method for formation of quadruple flat chain stitch. Ukraine Patent: UA 76292.

2. Kyiv National University of Technologies and Design. (2013). Regular sewing machine of four-thread chain stitch. Ukraine Patent: UA 78454.

3. Gorobets, V.A., Manoilenko, A.P. and Dvorghak, V.N. (2011). Analysis of the interaction of working organs of sewing machine of secret chain stitch. Bulletin of the Kyiv National University of Technologies and Design, 3, 9-15.

4. Pishchikov, V.O. and Orlovskiy, B.V. (2007). Design of Sewing Machines. Kyiv: Format. 